Technological University Dublin

DÜBLIN

ARROW@TU Dublin

2020

\title{
An Argument Against Sex Segregation in Post-Primary Schools: Examining Wellbeing Perspectives
}

David Byrne

TU Dublin - Blanchardstown Campus, david.byrne@tudublin.ie

Aiden Carthy

TU Dublin - Blanchardstown Campus, aiden.carthy@tudublin.ie

Follow this and additional works at: https://arrow.tudublin.ie/cassart

Part of the Social and Behavioral Sciences Commons

\section{Recommended Citation}

Byrne, D. \& Carthy, A. (2020) An Argument Against Sex Segregation in Post-Primary Schools: Examining Wellbeing Perspectives, PSYCHOLOGY \& SEXUALITY, DOI:10.1080/19419899.2020.1861072

This Article is brought to you for free and open access by the Centre for Applied Social Studies in Social Care at ARROW@TU Dublin. It has been accepted for inclusion in Articles by an authorized administrator of ARROW@TU Dublin. For more information, please contact arrow.admin@tudublin.ie, aisling.coyne@tudublin.ie, gerard.connolly@tudublin.ie.

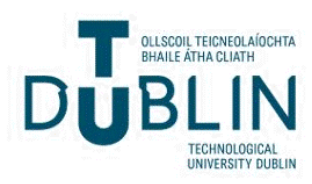




\section{An argument against sex segregation in post- primary schools: examining wellbeing perspectives}

\section{David Byrne \& Aiden Carthy}

To cite this article: David Byrne \& Aiden Carthy (2020): An argument against sex segregation in post-primary schools: examining wellbeing perspectives, Psychology \& Sexuality, DOI: 10.1080/19419899.2020.1861072

To link to this article: https://doi.org/10.1080/19419899.2020.1861072

\section{Published online: 24 Dec 2020.}

Submit your article to this journal $\sqsubset$

山ll Article views: 37

Q View related articles ๘

View Crossmark data $\nearrow$ 


\title{
An argument against sex segregation in post-primary schools: examining wellbeing perspectives
}

\author{
David Byrne (D) and Aiden Carthy (iD) \\ Department of Humanities, TU Dublin - Blanchardstown Campus, Ireland
}

\begin{abstract}
There currently exists a substantial body of research regarding the influence that the educational environment can bear upon the social and emotional wellbeing of male and female students. It has been highlighted that young female students tend to present with lower levels of wellbeing than do male students, and that the behaviour of male students may be implicit in this discrepancy. Some scholars have proposed sex segregation to be an appropriate palliative measure in addressing the lower measures of wellbeing observed among female students. This paper will present a counter-argument to this proposal based on two principal arguments. First, that sex segregation can have deleterious outcomes for female students and may reify the identity of young girls as 'weaker than', or 'needing protection from', young boys. Second, that sex segregation overlooks the performative aspect of gender and fails to account for male students who may perform a feminine gender-identity. Wellbeing perspectives from a post-primary context will be examined in relation to international research regarding both biological sex and socially constructed concepts of gender. It will be proposed that educational discourse that informs decisions to segregate the sexes be reconceptualised to include a broader understanding of students' needs and identities in relation to both sex and gender.
\end{abstract}

ARTICLE HISTORY

Received 17 July 2020

Accepted 2 December 2020

\section{KEYWORDS}

Sex segregation; gender; victim-identity; hegemony; education; wellbeing

\section{Introduction}

Previous research has demonstrated that pre-adolescent children can possess extremely high levels of optimism and can be largely resilient to adverse emotional states such as sadness, anxiety, fear, shame and guilt, or what is colloquially known as 'negative affect' (Stringer, 2013). When analysed according to sex, a more nuanced picture emerges, as pre-adolescent boys have been found to be marginally more likely to be depressed, and more likely to be more depressed, than girls (Seligman, 2011). Interestingly, this sex dichotomy is reversed by adulthood, as it has consistently been demonstrated that women are more likely than men to exhibit depressive symptoms, such as feelings of sadness or hopelessness, anxiety and loss of interest in previously enjoyed activities. Further, women are more likely to be diagnosed with depression than are men. When the disparity in each sex's experience of depressive symptoms is reversed, it is also exacerbated, with women experiencing a much more pervasive tendency towards negative affect (Albert, 2015; Jack, 1991; Kuehner, 2017). It is widely accepted that this shift tends to occur during adolescence (Bluth et al., 2016; Cyranowski et al., 2000; Salk et al., 2017), the time when children are entering into post-primary education. Some scholars have attributed lower measures of wellbeing among post-primary girls to 
the co-educational context and have advocated the single-sex context as a remedial factor (Mael et al., 2005). However, sex segregation perpetrated for the purpose of preserving female students' wellbeing may carry some troubling implications.

This article will present a critical argument against the perpetration of single-sex education as a measure to attend to the wellbeing of young girls in post-primary education. Considerations for wellbeing will adhere to eudaimonic principles, which emphasise the socially constructed nature of concepts of wellbeing, such as self-acceptance, personal growth and purpose in life (Dodge et al., 2012). Arguments against sex segregation will be made on the basis of both biological sex and socially constructed concepts of gender. The implications of student wellbeing will be related to sex through a discussion of differing relational experiences within the school context. The gendered aspect of student wellbeing will be highlighted in a socio-performative context and reconciled through Connell's (1995) hierarchy of masculinities, and a Gramsci (1971) understanding of hegemony. This will culminate in the proposal of further research, which may further contribute to the discourse regarding the single-sex/co-education debate.

It should be noted that discussions in this article will predominantly pertain to binary interpretations of sex as inferred by the all-boys/all-girls dichotomy of single-sex schools. While it is important to recognise the social construction of labels and categories associated with biological sex, insufficient scope exist within this paper to explore the fullest depths of these social constructions. Discussions of sex differences will be presented using the dichotomies 'boy/girl' and 'male/female', while gender differences will be discussed using the dichotomy 'masculine/feminine'. Again, insufficient scope exists within this article to examine fully the equally important reality of LGBTQI+ student experiences. However, consideration will be afforded to the implications of students of each binary sex performing non-normative gender roles.

\section{Wellbeing and the gendered student-identity}

A review of the literature conducted by Beaman et al. (2006) revealed that the common perception among students, teachers, parents and researchers was that boys tended to receive a larger share of teachers' attention in the classroom. The initial supposition was that boys garnered this extra attention by bringing criticism upon themselves in response to their greater propensity for externalising behaviour. This was seen to result in the differential in levels of teacher-initiated attention rather than a sex or gender bias (Brophy \& Good, 1970). However, Brophy and Good's findings were later contradicted by Kelly (1988), who's meta-analysis of over 80 studies on gender differences in teacher/pupil interactions found that boys received more instructional contacts, high-level questions, academic critiques and slightly more praise than did girls. In light of research which consistently identifies that girls outperform boys across most subjects (Crosnoe et al., 2008; Duckworth \& Seligman, 2006; Hartley \& Sutton, 2013), it may be plausible that this is the teachers' response to the academic shortcomings of male students. When considering the discrepancy in teacher attention, Myhill (2002) found that higher achieving girls were generally more compliant, to the point of conformity, and more willing to adhere to the rules of the classroom. Building upon this research, Beaman et al. (2006) proposed that the significant challenge posed to classroom management by boys, coupled with the general compliance of girls, has increasingly lead to teachers identifying the 'ideal pupil' as female or, more accurately, subscribing to the feminine construct of gender. They go on to say that, for male students, this perceived feminisation of the school environment can result in a dissonance between the student-identity and the culturally prescribed male gender-identity.

It has been argued that such a classroom dynamic can be developmentally maladaptive for boys and girls. Boys' non-malicious/non-aggressive externalising behaviours that playfully disrupt the classroom may be used in the construction of a masculinity in opposition to the sensible and academically directed femininity (Beaman et al., 2006). Perceived value dissimilarity (Struch \& Schwartz, 1989) can see boys pushed into gender-identity creation via differentiation from the other (in this case, the feminised student-identity). This can be further compounded, as many girls 
- and even some teachers - can find these behaviours amusing and endearing, reinforcing and pathologising boys towards inappropriate classroom behaviour (Francis, 2002). Conversely, girls can arguably be seen to be socialised into a gender-identity of compliance and conformity. Myhill (2002) argued that the degree of compliance that can be seen in female students is only advantageous to teachers, in terms of classroom management, for example, and may result in meek subservience upon eventual entry into the labour market. This gender aspect of the 'hidden curriculum' can result in a cyclical relationship of girls' emotional servicing of boys and boys reinforcing the preferred 'feminine' student-identity, perpetuating the gender roles Francis (2002, p. 118-119) referred to as 'silly boys and sensible girls'.

Socialisation into gender roles/identities begins long before entry into post-primary education. Goleman (1996) argued that parents are significantly more likely to expose girls to more information about emotions than they are boys. This may help to explain why girls are often more capable of identifying their emotions than boys. That said, when boys do identify a negative emotional state, they tend to be more likely to attempt to pursue palliative measures, while girls can often become trapped in a cycle of self-analysis (Seligman, 2011). The palliative measures pursued by boys can often be maladaptive and disruptive, contributing to the 'silly boy/sensible girl' gender roles. However, a cycle of self-analysis, to which girls may be more susceptible, can lead to the onset of 'pessimism-rumination'. This can occur when a threat exists to which an individual believes himself or herself to be helpless. Permanent and pervasive explanatory styles, which girls can often be more likely to exhibit, may lead to pessimism and the expectation of helplessness with regard to future situations. Seligman (2011) argued that the manifestation of such a consciousness could lead to the onset of depressive symptoms, such as feelings of sadness or hopelessness, anxiety and loss of interest in previously enjoyed activities.

It could be argued that phenomena such as pessimism-rumination may be more persistent and pervasive than disruptive palliative measures. Research has identified that, while levels of wellbeing tend to decrease among boys and girls when transitioning from primary to post-primary education, girls tend to demonstrate more pervasive trends towards negative affect than do boys. These trends were seen to be particularly pronounced with regard to differences in life satisfaction, academic selfimage, body self-image and freedom from anxiety (Doyle \& Gavin, 2006; Smyth, 2015). Such trends were acutely observed among Irish schoolgirls in research conducted on behalf of the World Health Organisation (Inchley et al., 2016). For example, Inchley et al. found that $40 \%$ of 13 -year-old girls felt pressured by schoolwork compared to $66 \%$ of fifteen-year-old girls, while $34 \%$ of 13 -year-old boys felt pressured by schoolwork compared to $48 \%$ of 15 -year-old boys. This example suggests that academic anxiety may increase over the course of post-primary education. Furthermore, $36 \%$ of $13-$ year-old girls felt 'too fat' compared to $49 \%$ of 15 -year-old girls, while $18 \%$ of 13 -year-old boys felt 'too fat' compared to $22 \%$ of 15 -year-old boys. This points towards an increase in social anxiety over the course of post-primary education. In both examples, a particular propensity towards negative affect can been noted among girls.

\section{Single-sex/co-educational schools}

A trend of perpetrating sex segregation to enhancing learning experiences can be seen at an international level (Jackson, 2002). International research has also found that parents tend towards a very positive perception of the influence of single-sex schools upon their children's social and emotional wellbeing, particularly among parents of girls (Tichenor et al., 2012). However, research into the benefits of single-sex vs co-educational schools has produced varied results. One metaanalysis of the literature suggested that single-sex schools showed greater academic performance than co-educational schools. It was further purported that the benefits of single-sex schools are clearer and more pronounced in girls schools than in boys schools (Mael et al., 2005). Additional research identified particular benefits of single-sex schooling for girls regarding increased selfesteem, self-concept, confidence in academic learning, and a sense of ownership of their class 
(Streitmatter, 2012; United Nations Educational, Scientific and Cultural Organization (UNESCO), 2007). On the contrary, large-scale reviews in Great Britain, Canada, Australia and New Zealand found little overall difference between single-sex and co-educational schools with regard to academic outcomes (Halpern et al., 2011). However, it has been noted that boys tend to report higher levels of self-esteem in co-educational schools than in single-sex schools (Mael et al., 2005). Research conducted in both Australia and England, in which transitions from single-sex to co-educational classes were analysed, may go some way to clarifying the influence of school-type upon academic achievement and wellbeing.

The Australian research took place in two post-primary schools in Sydney over a 5-year period (Marsh et al., 1988). It was found that academic achievement remained stable across the 5-year period of the study, which was considered to contradict the dominant view that single-sex schools were more beneficial to academic achievement. Measures of wellbeing, such as student self-concept, initially dipped but then rose to higher levels than were previously recorded. The second phase of this study, conducted ten years later, identified that measures of wellbeing remained at this higher level. The English research took place in an inner city comprehensive school in the south-west (Jackson \& Smith, 2000). The findings of this study were more polarised with girls having a more favourable perception of single-sex classes and boys having a more favourable perception of coeducational classes. Boys' behaviour in co-educational schools was perceived to be dominating and disruptive, while girls were perceived to have had a civilising effect on boys. The findings also supported the dominant view that single-sex schools can be beneficial to wellbeing on some measures (such as confidence), while other measures (such as academic self-concept) showed no change. It was also suggested that it would be less likely for gender-typing of curriculum subjects to occur in single-sex schools than in co-educational schools. That said, while it could be considered that the single-sex context may reduce gender comparisons of what constitutes 'male' and 'female' subjects, it could be counter argued that school policies with regard to curriculum selection in a single-sex context can result in the provision of a gendered curriculum. As such, the gender-typing of curriculum subjects in a single-sex context could become more subversive and difficult to identify. Furthermore, it has been proposed that the variance in levels of wellbeing between single-sex and co-educational schools is likely to be influenced by other variables such as schools' selective intake of students, parental influence, and socioeconomic background (Jackson \& Smith, 2000; Riordan, 1999; Salomone, 2002).

Discourse regarding the impact of school type on academic achievement would seem to lack consensus. While some would argue that all-girls schools outperform all-boys and co-educational schools academically, others argue that controlling for variables such as school intake and socioeconomic background would result in no significant difference between school types ( $O^{\prime}$ Connor, 2017). In addition, while one line of research suggests that single-sex schools close the gender-gap with regard to science, technology, engineering and maths, or 'STEM subjects' (IWish, 2016), another suggests that they exacerbate it (Doris et al., 2013). However, research suggests that, while gender stereotypes can manifest in co-educational schools, they may be more likely to develop in single-sex schools, with boys in all-boys schools tending to become increasingly aggressive, while girls in allgirls schools tend to become increasingly gender-typed (Halpern et al., 2011). Students of single-sex schools may also be more likely to develop stereotypical views of the opposite sex (Stromquist, 2007).

A survey conducted in one Irish post-primary school suggested that male and female students might benefit from a co-educational environment. The school is usually all-boys for the junior-cycle but admits girls in fifth and sixth year who wish to study STEM subjects for their final exams (i.e. the leaving certificate). Girls reported a largely positive perception of the co-educational context, highlighting the more relaxed atmosphere in comparison to the 'hectic, highly strung and stressful atmosphere' of all-girls schools (Fehily, 2016 n.p.). The 'stressful atmosphere' these girls spoke of is an implicit factor in the increased measurement of negative outcomes such as eating pathology that have been documented in all-girls schools (Bould et al., 2016). The 'civilising effect' of girls noted 
earlier could be argued to be evident as the school principal reported that very few incidents of bullying tended to occur in fifth and sixth year (Fehily, 2016). In this regard, co-educational schooling appeared to be mutually beneficial to the wellbeing of male and female students. It could also be suggested from this example that remedial, cooperative and positive interactions between genders may be less difficult to implement in co-educational schools than in single-sex schools.

\section{The construction of a gendered victim-identity in education}

Mael et al.'s (2005) findings that single-sex schools produce more pronounced benefits for girls than boys could be cited to advocate for single-sex schooling as a reprieve for girls from the dominant, externalising behaviour of boys. However, this may be failing to appreciate fully the complexity of identity formation among adolescents in an educational context. While the manifest function of sex segregation may be an attempt to promote positive outcomes, a severe latent function can be proposed in that this course of action may reify the identity of young girls as 'weaker than', or 'needing protection from', young boys. Whether it be educational policy that sanctions the designation of single-sex schools (or single-sex classes within co-educational schools) or parental influence that seeks to reduce the potential for duress for their children, it could be hypothesised that the withdrawal of girls from co-education can carry the connotation that girls have fallen victim to the dominant behaviour of boys and intervention is necessary.

When understanding the designation of victimhood as an interactional practice, identifying a person/group as a victim in social discourse goes beyond reporting a perceivable social reality by actually contributing to the constitution of that social reality (Holstein \& Miller, 1990). In this sense, victimhood is a categorisation device that is accompanied by an interpretive framework, which provides instruction as to how to understand specific types of social relationships (Sacks, 1972). The designation of victimhood can serve one (or more) of three functions. Victim descriptions can be reflexive, providing instruction as to how to appreciate contextually specific meanings of a person/ group as a victim and simultaneously entreating and constructing these meanings. They can also be indexical and take their sense and meaning from the context of their production or designation. Finally, victim descriptions can be rhetorical, offering partisan solicitations of others to perceive, and act upon, preferred understandings or interpretations of a person/group and their circumstances (Holstein \& Miller, 1990).

The consideration of a person/group as a victim encourages others to see how the person/group has been wronged by forces beyond their control while simultaneously establishing the 'fact' of having been wronged, and that the responsibility for having been wronged lies outside of the victim (Holstein \& Miller, 1990). Parents and policy makers may see - and encourage others to see - girls as not responsible for their lower measures of wellbeing in a co-educational environment. While this behaviour may be perpetrated with the best of intentions, it may inadvertently encouraging the perception of female students through the prism of a victim-identity. Further compounding this issue, research has demonstrated that the female tendency when victimised can be to internalise blame (Stanko \& Hobdell, 1993). As such, the reflexive function of the victim identity could result in a social perception of girls as victims, which would remove responsibility from girls to challenge the dominant position of boys, while the self-perception among girls may contribute to an internalised subordination to boys. The social perception of girls as having been wronged by forces beyond their control is arguably detrimental to girls' individual agency and actualising tendency as they are assumed incapable of remedying the situation and are largely absolved of the responsibility of challenging the dominant behaviour of boys. This phenomenon, which closely mirrors learned helplessness, is a central tenant of Labelling Theory, whereby victims can learn to perform the passive and restrained role that is associated with the victim identity (Van Dijk, 2009).

The converse of this argument is the problematic relationship between masculinity and the victim-identity. As discussed by Mael et al. (2005), increased measures of wellbeing among boys in a co-educational setting would suggest that boys tend to prefer a co-educational setting. It could 
therefore be considered that boys would be wronged by sex segregation perpetrated on the basis of educational policy or parental preference. By overlooking boys' autonomy and placing them in their less preferred context of all-boys schools, it could be argued that boys may fall victim to educational policy or parental preference perpetrated in order to address the lower measures of wellbeing observed among girls. As discussed earlier, inherent in the victim-identity is the opportunity for the abandonment of responsibility. As opposed to girls who may internalise blame, boys have been observed to lean into the abandonment of responsibility, as the male tendency when victimised is to externalise blame (Stanko \& Hobdell, 1993). This, it is argued, would be to protect the image of 'superior maleness', as boys could argue that the source of trauma is simply outside of their control. A rudimentary example of how this may manifest can be seen in the use of an external explanatory style, e.g., arguing 'the test was too hard' rather than 'I needed to study more for the test'.

The victim-identity is incongruent with the supposed strong and superior identity of masculinity. If a male is to fit into the highest order of masculinity - what Connell (1987) referred to as 'hegemonic masculinity' - to be discursively produced as a victim could result in cognitive dissonance. Burcar and Åkerström (2009) proposed that a typically male solution to this would be to transform the shameful into the culturally praised. A somewhat maladaptive method of actioning this can be demonstrated using Bourdieu's (2013) framework of 'fields', 'capital', and 'habitus'. Through Bourdieu's framework, the school would be the field in which the social interaction would be taking place. Social capital may be attained in the form of positive acknowledgement from peers and teachers, while cultural capital may be attained as a reward for academic success (e.g., junior certificate). Habitus would be the normative social behaviours, in this case, ascribed by teachers and followed by students. If boys were to feel victimised by the educational system, cognitive dissonance can be alleviated by rejecting the habitus of the current field and establishing a new habitus, often within a new field (e.g., the playground). This could manifest as a subculture of aggression and disruptive externalising behaviour (Skelton, 1997), but may more typically present as a subculture of 'laddishness' (Jackson, 2003).

Features that have been observed to be common amongst laddish boys included 'hanging around' with friends, observing a particular dress sense, playing sports, and not being seen to work hard at schoolwork, as this was deemed to be 'not cool' (Jackson, 2003). Jackson observed several strategies that 'laddish' boys tended to employ to circumvent the potential dissonance between the prevailing negative perception of academia and the implications of academic failure. These include avoiding the appearance of working and promoting the appearance of effortless achievement, the intentional withdrawal of effort and a rejection of academic work, and engaging in disruptive behaviour. However, even though schoolwork was deemed uncool, Jackson noted that boys who typically understood the importance of doing well in school and who harboured a desire to succeed academically would employ these strategies. Utilising these strategies could minimise the low self-worth that may result from academic failure (Schunk \& DiBenedetto, 2016). Jackson (2003) made the further observation that laddish boys may employ these strategies to protect against the 'feminine' identity of the 'good student'. As alluded to earlier, studies have found that schoolwork and academic application can often be perceived as feminine endeavours (Heyder \& Kessels, 2015, 2016: Renold, 2001). Jackson (2003) noted that boys who wish to succeed academically must do so in the perceived absence of effort, as to be seen to apply effort to academia would be to risk being labelled as feminine. Interestingly, when Jackson asked boys what lads do and do not do, they often responded by referring to things that they perceived girls do not do and do, respectively. Essentially, Jackson's research found that, in a post-primary context, boys constructed the hegemonic 'laddish' masculinity antithetically to the feminine.

Further complication arises when considering Connell's (1995) proposition of a stratified substructure of masculinities that exists subjacent to hegemonic masculinity. 'Complicit masculinities' do not necessarily embody hegemonic masculinity but are reflective of, and largely benefit from, the patriarchal dividend. ' 'Marginalised masculinities' fail to conform to hegemonic masculinity on some socio-cultural characteristic, e.g., being disabled or non-white (in a western culture). Finally, 'subordinated masculinities' lack many of the qualities of hegemonic masculinity or express qualities that 
are contrary to those of hegemonic masculinity e.g., gay males or heterosexual males who present as feminine or non-normative (Connell, 1995). In the absence of the civilising effect of girls, the more aggressive environment of single-sex boys' schools (Halpern et al., 2011) can see the lesser masculinities become increasingly likely to fall victim to hegemonic males exercising their alternative habitus (i.e. teasing/bullying) (Delfabbro et al., 2006). In this situation, the lesser masculinities can be coerced into adopting the victim-identity by hegemonic masculinity, demonstrating that girls and boys can be victimised by boys' externalising 'laddish' behaviour.

Connell (1987) argued that a hegemonic femininity would be impossible as all forms of femininity are constructed in the context of the subordination of women to men. However, this can be challenged when considering Gramsci's (1971) original conceptualisation of hegemony. Gramsci proposed that hegemony is a method by which dominant groups maintain their ascendency by convincing oppressed groups that the established order is in the greater interest. Dominant groups would allow the subverted ascension of sub-groups within the oppressed if these sub-groups served to further the agenda of the dominant groups. Pyke and Johnson (2003) summarise this point with regard to gender:

Whereas hegemonic masculinity is a superstructure of domination, hegemonic femininity is confined to power relations among women. However, the two structures are interrelated with hegemonic femininity constructed to serve hegemonic masculinity, from which it is granted legitimacy. (p. 51)

Pyke and Johnson posit that, rather than just being the dominant masculine identity, hegemonic masculinity is the dominant form of identity over all other possible forms of identity. From this position, it could be argued that hegemonic masculinity is 'the' hegemonic identity, under which, all other identities (and all other hegemonic identities) are subsumed. This would include a hegemonic femininity.

In arguing against the possibility of a hegemonic femininity, Connell (1987, p. 188) stated, 'femininity organised as an adaptation to men's power, and emphasising compliance, nurturance, and empathy as womanly virtues, is not in much of a state to establish hegemony over other kinds of femininity'. However, emphasising masculinity and constructing femininity as the 'other' to masculinity is a practice that is widely contested within the literature (see Dahl, 2012; Paechter, 2018; Schippers, 2007). Contrary to Connell's position, rather than being constructed 'in response to', or 'as an adaption to' masculinity, Schippers (2007, p. 94) suggested that hegemonic femininity may be understood to be the expression of feminine characteristics that 'establish and legitimate a hierarchical and complementary relationship to hegemonic masculinity and that, by doing so, guarantee the dominant position of men and the subordination of women'. Like Pyke and Johnson (2003), Schippers' (2007) position is congruent with Gramsci's (1971) original conceptualisation of hegemony in that hegemonic masculinity is viewed to be the truly dominant group that legitimises the subverted power of the subordinate hegemonic femininity. In this sense, hegemonic femininity can be seen to be utilised (by hegemonic masculinity) as a representation of the preferred feminine attitudes, behaviours, etc. to which all other femininities would be expected to strive. This can be observed in the preferred feminine student-identity, which can socialise girls into a tendency towards submissiveness.

Gramsci (1971) went on to state that while hegemony was perpetrated preferably through consent so as to render the oppressed group unaware as to the full extent to which they were being controlled, a willingness to use coercive force would typically be clearly and pervasively communicated. Paechter employed the Foucaultian perspective (Foucault 1980, 1982) that power relations are fluid and constantly contested, and that where there is power there is resistance, to explore this relationship dynamic in an educational context. Across several studies, Paechter demonstrated that hegemonic girls ${ }^{2}$ did not perform the male-focused 'emphasised femininity' described by Connell (1987), but rather exercised independence and maintained a constant resistance to their subservient position (see Paechter, 2007; 2018; Paechter \& Clark 2015). 
Hegemonic girls were found to mobilise considerable resources in establishing an oppositional counter-discourse to the Gramscian hierarchy of gender-identities, and were also found to be capable of exercising considerable power with regard to non-hegemonic boys as well as girls (Paechter, 2007; 2018; Paechter \& Clark, 2015; Renold, 2005). However, across the aforementioned studies, it was consistently found that hegemonic girls were simply unable to compete with hegemonic boys and were quickly sanctioned for any perceived challenges to the boys' dominance. As hegemonic femininity was legitimised to serve the purpose of hegemonic masculinity, counterdiscourse could never reach the point of counter-hegemony.

Schippers (2007) argued that if hegemonic femininity were to be constructed within the context of an idealised relationship between masculinity and femininity, then refusal to compliment hegemonic masculinity would be regulated with immediate social sanction and stigmatisation. Schippers stated that the criteria for such refusal could include failure to demonstrate a desire to be the object of masculine desire; promiscuous behaviour; generalised non-compliance, and; overtly aggressive behaviour. All of these behaviours could be perceived to be reflective of girls attempting to perform hegemonic masculinity. Schippers expanded this argument to challenge Connell's (1995) hierarchy of masculinities. Schippers (2007) proposed that, because gender hegemony is legitimated by the preservation of a hierarchical relationship between masculinities and femininities, there are no characteristics of masculinity that are stigmatised as subordinate. Rather, what Connell identified to be subordinate masculinities, are in fact instances of hegemonic femininity performed by males, and that the devaluation of such individuals was due to the perception of them as feminine. If a male were to perform hegemonic feminine characteristics, such as seeking to be the object of masculine desire, physical weakness, compliance, or overt non-aggression, he would become the target of social sanction, much like females who perform features of hegemonic masculinity. Schippers' research highlights an important concept in that (hegemonic) gender identities are not fixed and immutable, and that either may be performed by males or females. More crucially, it is demonstrated that the masculine gender-identity is only hegemonic when performed by (a select few) males, and that hegemonic femininity is only legitimised when performed by (a select few) females.

\section{Directions for future research}

The available research suggests that the assigning of gender roles and the assumption of genderidentities within an educational context can bear an explicit influence upon the differential in boys' and girls' levels of social and emotional wellbeing. While it could be considered that sex segregation would be an acceptable palliative measure to improve girls' overall wellbeing and self-concept, several issues have been identified that may have long-term latent implications for boys and girls. Furthermore, a Gramscian approach to gender identity (Gramsci 1971), particularly from the perspective of Schippers (2007), may have significant implications with regard to the understanding of victimhood in an educational context. As such, it is proposed that further research is necessary to examine the plausibility of the manifestation of a uniquely male and a uniquely female victimidentity in response to sex segregation in an educational setting.

First, it could be hypothesised that sex segregation may result in girls being labelled with a victim-identity, which may potentially contribute to an acceptance of their perceived powerlessness in the face of boys' dominance. This may be mediated by a hierarchy of hegemonic gender-identities in accordance with Gramscian theory (Gramsci, 1971). While it should be noted that Paechter's (2018) approach to hegemonic femininity differs from - and critiques - the approach taken by Schippers (2007), both studies, along with others such as Jackson (2003) and Pyke and Johnson (2003), support the conceptualisation of hegemonic femininity as an identity construct that serves to maintain the status quo of hegemonic masculine dominance. Interestingly, it could be hypothesised that hegemonic femininity may actually be more prominent among girls within a single-sex context as girls have been found to become more gender-typed in such a context (Halpern et al., 2011). George's (2007) research found that girls who performed 
hegemonic femininity within all-female peer groups (girls George termed 'Queen Bees') were seen as exceptionally kind and helpful by their teachers, but often perceived to be mean or naughty by their lesser peers. This was argued to reflect wider conceptions of hegemonic femininity as subordinate to masculinity, while preserving dominance over other femininities. If hegemonic femininity were found to be more prominent in a single-sex environment, there may be implications with regard to the reproduction of the 'dominant but underperforming boys/academically accomplished but submissive girls' gender continuum.

Girls may be victimised by placement in a single-sex context as: (1) they may be perceived to be helpless against the dominant behaviour of boys, reifying their identity as 'lesser than' or 'needing protection from' boys, and; (2) in a single-sex context, girls may actually be more likely to be socialised into a submissive gender-norm. As such, it may be pertinent to ask the question of whether or not typically feminine indicators of victimhood such as pessimism rumination are present or more prevalent among hegemonic or non-hegemonic girls, and if these indicators of victimhood are more prevalent in a single-sex or co-educational context.

Second, when considering that boys' academic performance and measures of social and emotional wellbeing have been found to be lower in single-sex environments than in co-educational environments, it could be hypothesised that victimisation of boys at the hands of a 'feminised' education system may be compounded by the implementation of sex segregation. As it has been observed that single-sex male educational environments can be more aggressive, this victimhood may be exacerbated among boys who perform what Connell (1995) referred to as marginalised masculinities, but who may alternatively be understood to perform hegemonic femininity (Schippers, 2007). Jackson's (2003) research demonstrates that hegemonic boys may utilise perceived value dissimilarity to strengthen the identity of hegemonic masculinity by describing it as opposed to the feminine. It could be argued that, in the absence of girls, marginalised/hegemonic feminine boys may be further coerced into the feminine gender-role via perceived value dissimilarity. It may therefore be fruitful to ask whether or not typically feminine indicators of victimhood such as pessimism-rumination would be present or more prominent among boys who perform hegemonic femininity, or whether pessimism-rumination would be more likely to occur among such boys in a single-sex environment or in a co-educational environment. It could also be examined whether or not typically masculine responses to victimhood, such as bravado and the externalisation of blame, are more likely to be demonstrated by boys who perform hegemonic masculinity, or are more likely to occur in a single-sex or co-educational context.

\section{Conclusion}

In the mid '90s, Connell (1995) made the argument that, while schools have been a rich site for the study of the reproduction of masculinities, there was surprisingly little examination of the roll of education in the transformation of masculinity. This is arguably still true today, and arguably true of the transformation of femininity. Each respective gender-identity presents a unique set of challenges to the social and emotional wellbeing of adolescents that can persist into adulthood. Education is a prominent context in which the socialisation of young people takes place and socially acceptable gender roles are learned. As such, it may be axiomatic that some of the more maladaptive aspects of gender-identity formation may be unwittingly nurtured within an educational context. That this is largely unacknowledged - or at least unactioned - in educational discourse is evidenced by the prevailing perception among some scholars that the segregation of the sexes is an appropriate remedial action to attend to female students' lower measures of wellbeing. Two principal arguments can be levied against this approach. First, the research regarding the benefits of single-sex education for girls is by no means conclusive, and this motivation for segregation could result in the reification of a victim-identity among young girls. Second, gender is not exclusively performed by one sex. Sex segregation arguably completely overlooks the issue of femininity performed by young boys. Indeed, it may be necessary to reconceptualise the argument of 'oppressive boys and subjugated 
girls' to 'oppressive masculinities and subjugated femininities' within educational discourse. This paper by no means explores the fullest depths of this issue. However, the isolated example of student wellbeing arguably highlights the need to understand more fully students' needs - and indeed identities - before actioning remedial measures.

\section{Notes}

1. Connell identifies the patriarchal dividend as 'the advantage to men as a group from maintaining an unequal gender order'. These advantages can include increased authority, respect, safety, institutional power and emotional support (R. Connell, 2009, p. 142).

2. So as not to conflate sex and gender, it is important to note that the terms 'hegemonic boys/girls' and 'nonhegemonic boys/girls' are in specific reference to the sex-type 'boys/girls' who perform the hegemonic 'gendertype' masculinity/femininity and non-hegemonic gender-type 'masculinities/femininities' respectively.

\section{Disclosure statement}

No potential conflict of interest was reported by the authors.

\section{Funding}

Technological University Dublin Research Scholarship

\section{Notes on contributors}

David Byrne is a research scholar based at the Blanchardstown Campus of TU Dublin. David's primary areas of research interest are mental health/wellbeing, group dynamics, and gender. David is currently conducting his PhD research, which examines Irish post-primary educators' attitudes regarding the promotion of student social and emotional wellbeing.

Aiden Carthy directs the Research Centre for Psychology, Education and Emotional Intelligence (PEEI) which is located on the Blanchardstown Campus of Technological University Dublin. Aiden's principal areas of research interest are mental health and applied education. Specifically, Aiden's work focuses on using emotional intelligence coaching to enable educators, students and others to reach their maximum potential and on research related to student support and educational design.

\section{ORCID}

David Byrne (iD) http://orcid.org/0000-0002-0587-4677

Aiden Carthy (iD http://orcid.org/0000-0002-4153-7889

\section{References}

Albert, P. (2015). Why is depression more prevalent in women? Journal of Psychiatry and Neuroscience, 40(4), $219-221$. https://doi.org/10.1503/jpn.150205

Beaman, R., Wheldall, K., \& Kemp, C. (2006). Differential teacher attention to boys and girls in the classroom. Educational Review, 58(3), 339-366. https://doi.org/10.1080/00131910600748406

Bluth, K., Campo, R. A., Futch, W. S., \& Gaylord, S. A. (2016). Age and gender differences in the associations of self-compassion and emotional well-being in a large adolescent sample. Journal of Youth and Adolescence, 46(4), 840-853. https://doi.org/10.1007/s10964-016-0567-2

Bould, H., De Stavola, B., Magnusson, C., Micali, N., Dal, H., Evans, J., Dalman, C., \& Lewis, G. (2016). The influence of school on whether girls develop eating disorders. International Journal of Epidemiology, 45(2), 480-488. https://doi.org/10. 1093/ije/dyw037

Bourdieu, P. (2013). Outline of a theory of practice. Cambridge University Press.

Brophy, J. E., \& Good, T. L. (1970). Teachers' communication of differential expectations for children's classroom performance: Some behavioral data. Journal of Educational Psychology, 61(5), 365-374. https://doi.org/10.1037/ h0029908 
Burcar, V., \& Åkerström, M. (2009). Negotiating a victim identity: Young men as victims of violence. Journal of Scandinavian Studies in Criminology and Crime Prevention, 10(1), 37-54. https://doi.org/10.1080/14043850902815073

Connell, R. (2009). Gender: In world perspective (2nd ed.). Polity.

Connell, R. W. (1995). Masculinities. Polity Press.

Connell, R. W. (1987). Gender and power: Society, the person and sexual politics. Polity.

Crosnoe, R., Riegle-Crumb, C., Field, S., Frank, K., \& Muller, C. (2008). Peer group contexts of girls' and boys' academic experiences. Child Development, 79(1), 139-155. https://doi.org/10.1111/j.1467-8624.2007.01116.x

Cyranowski, J. M., Frank, E., Young, E., \& Shear, M. K. (2000). Adolescent onset of the gender difference in lifetime rates of major depression. Archives of General Psychiatry, 57(1), 21-27. https://doi.org/10.1001/archpsyc.57.1.21

Dahl, U. (2012). Turning like a femme: Figuring critical femininity studies. NORA - Nordic Journal of Feminist and Gender Research, 20(1), 57-64. https://doi.org/10.1080/08038740.2011.650708

Delfabbro, P., Winefield, T., Trainor, S., Dollard, M., Anderson, S., Metzer, J., \& Hammarstrom, A. (2006). Peer and teacher bullying/victimization of South Australian secondary school students: Prevalence and psychosocial profiles. British Journal of Educational Psychology, 76(1), 71-90. https://doi.org/10.1348/000709904×24645

Dodge, R., Daly, A., Huyton, J., \& Sanders, L. (2012). The challenge of defining wellbeing. International Journal of Wellbeing, 2(3), 222-235. https://doi.org/10.5502/ijw.v2i3.4

Doris, A., O'Neill, D., \& Sweetman, O. (2013). Gender, single-sex schooling and maths achievement. Economics of Education Review, 35, 104-119. https://doi.org/10.1016/j.econedurev.2013.04.001

Doyle, P., \& Gavin, A. (2006). Emotional well-being among school children in ireland (16). http://www.nuigalway.ie/hbsc/ documents/fs_16_2006_july09.pdf

Duckworth, A. L., \& Seligman, M. E. (2006). Self-discipline gives girls the edge: Gender in self-discipline, grades, and achievement test scores. Journal of Educational Psychology, 98(1), 198-208. https://doi.org/10.1037/0022-0663.98.1. 198

Fehily, R. (2016). The Leap to Co-Ed: 'Mixed Classes are a Shock to the System'. Independent [Dublin]. Retrieved May 10 2020, from. https://www.irishtimes.com/news/education/the-leap-to-co-ed-mixed-classes-are-a-shock-to-thesystem- 1.2636332

Foucault, M. (1982). The subject and power. In H. L. Dreyfus \& P. Rabinow (Eds.), Michel Foucault, beyond structuralism and hermeneutics (pp. 208-226). Harvester.

Foucault, M. (1980). Power/knowledge. a selected interviews and other writings 1972-77. Pantheon Books.

Francis, B. (2002). Boys, girls and achievement: Addressing the classroom issues. Routledge.

George, R. (2007). Girls in a goldfish bowl: Moral regulation, ritual and the use of power amongst inner city girls. Sense Pub. Goleman, D. (1996). Emotional intelligence: Why it can matter more than IQ. Bloomsbury.

Gramsci, A. (1971). Selections from the prison notebooks of antonio GRAMSCI. Q. Hoare and G. Nowell-Smith (Eds.). Lawrence and Wishart Trans.

Halpern, D. F., Eliot, L., Bigler, R. S., Fabes, R. A., Hanish, L. D., Hyde, J., Liben, L. S., \& Martin, C. L. (2011). The Pseudoscience of Single-Sex Schooling. Science, 333(6050), 1706-1707. https://doi.org/10.1126/science.1205031

Hartley, B. L., \& Sutton, R. M. (2013). A stereotype threat account of boys' academic underachievement. Child Development, 84(5), 1716-1733. https://doi.org/10.1111/cdev.12079

Heyder, A., \& Kessels, U. (2016). Boys don't work? On the psychological benefits of showing low effort in high school. Sex Roles, 77(1-2), 72-85. https://doi.org/10.1007/s11199-016-0683-1

Heyder, A., \& Kessels, U. (2015). Do teachers equate male and masculine with lower academic engagement? How students' gender enactment triggers gender stereotypes at school. Social Psychology of Education, 18(3), 467-485. https://doi.org/10.1007/s11218-015-9303-0

Holstein, J. A., \& Miller, G. (1990). Rethinking victimization: An Interactional approach to victimology. Symbolic Interaction, 13(1), 103-122. https://doi.org/10.1525/si.1990.13.1.103

Inchley, J., Currie, D., Young, T., Samda, O., Torsheim, T., Augustson, L., \& Mathison, F. (2016). Growing up unequal: Gender and socioeconomic differences in young people's health and well-being; health behaviour in school-aged children (HBSC) study: International report from the 2013/2014 survey (7). http://www.euro.who.int/_data/assets/pdf_file/0003/ 303438/HSBC-No.7-Growing-up-unequal-Full-Report.pdf?ua=1

IWish. 2016. 2016 study of female students' attitudes to STEM. http://www.iwish.ie/wp-content/uploads/2016/10/iwishbrochure2016-web00.pdf

Jack, D. C. (1991). Silencing the self: Women and depression. Harvard University Press.

Jackson, C. (2003). Motives for 'laddishness' at school: Fear of failure and fear of the 'feminine'. British Educational Research Journal, 29(4), 583-598. https://doi.org/10.1080/01411920301847

Jackson, C. (2002). Can single-sex classes in co-educational schools enhance the learning experiences of girls and/or boys? An exploration of pupils' perceptions. British Educational Research Journal, 28(1), 37-48. https://doi.org/10. 1080/01411920120109739

Jackson, C., \& Smith, I. D. (2000). Poles apart? An exploration of single-sex and mixed-sex educational environments in Australia and England. Educational Studies, 26(4), 409-422. https://doi.org/10.1080/03055690020003610

Kelly, A. (1988). Gender differences in teacher-pupil interactions: A meta-analytic review. Research in Education, 39(1), 1-23. https://doi.org/10.1177/003452378803900101 
Kuehner, C. (2017). Why is depression more common among women than among men? The Lancet Psychiatry, 4(2), 146-158. https://doi.org/10.1016/s2215-0366(16)30263-2

Mael, F. A., Alonso, A., Gibson, D., Rogers, K., \& Smith, M. (2005). Single-sex versus coeducational schooling: A systematic review. U.S. Department of Education, Office of Planning, Evaluation and Policy Department, Policy and Program Studies Service.

Marsh, H. W., Smith, I. D., Marsh, M., \& Owens, L. (1988). The transition from single-sex to coeducational high schools: Effects on multiple dimensions of self-concept and on academic achievement. American Educational Research Journal, 25(2), 237-269. https://doi.org/10.3102/00028312025002237

Myhill, D. (2002). Bad boys and good girls? Patterns of interaction and response in whole class teaching. British Educational Research Journal, 28(3), 339-352. https://doi.org/10.1080/01411920220137430

O'Connor, W. (2017). All-girls schools send more pupils on to universities. Independent [Dublin]. https://www.indepen dent.ie/irish-news/education/school-league-tables/allgirls-schools-send-more-pupils-on-to-universities-35404140. html

Paechter, C. (2018). Rethinking the possibilities for hegemonic femininity: Exploring a gramscian framework. Women's Studies International Forum, 68, 121-128. Retrieved January 30, from. https://doi.org/10.1016/j.wsif.2018.03.005

Paechter, C. (2007). Being boys, being girls: Learning masculinities and femininities. Open University Press.

Paechter, C., \& Clark, S. (2015). Being 'nice' or being 'normal': Girls resisting discourses of 'coolness'. Discourse: Studies in the Cultural Politics of Education, 37(3), 457-471. https://doi.org/10.1080/01596306.2015.1061979

Pyke, K. D., \& Johnson, D. L. (2003). Asian American women and racialized femininities. Gender and Society, 17(1), 33-53. https://doi.org/10.1177/0891243202238977

Renold, E. (2005). Girls, boys, and junior sexualities: Exploring children's gender and sexual relations in the primary school. Routledge Falmer.

Renold, E. (2001). Learning the 'hard' way: Boys, hegemonic masculinity and the negotiation of learner identities in the primary school. British Journal of Sociology of Education, 22(3), 369-385. https://doi.org/10.1080/01425690123433

Riordan, C. (1999). The silent gender gap: Reading, writing, and other problems for boys. Education Week, 19(12), 46-49. https://www.edweek.org/ew/articles/1999/11/17/12riordan.h19.html

Sacks, H. (1972). An initial investigation of the usability of conventional data for doing sociology. In D. Sundow (Ed.), Studies in social interaction (pp. 31-73). The Free Press.

Salk, R. H., Hyde, J. S., \& Abramson, L. Y. (2017). Gender differences in depression in representative national samples: Meta-analyses of diagnoses and symptoms. Psychological Bulletin, 143(8), 783-822. https://doi.org/10.1037/ bul0000102

Salomone, R. C. (2002). Same, different, equal: rethinking single-sex schooling. Yale University Press.

Schippers, M. (2007). Recovering the feminine other: Masculinity, femininity, and gender hegemony. Theory and Society, 36(1), 85-102. https://doi.org/10.1007/s11186-007-9022-4

Schunk, B. H., \& DiBenedetto, M. K. (2016). Self-efficacy theory in education. In K. R. Wentzel \& D. B. Miele (Eds.), Handbook of motivation at school (2nd ed., pp. 34-54). Routledge.

Seligman, M. E. (2011). Learned optimism. William Heinemann Australia.

Skelton, A. (1997). Studying hidden curricula: Developing a perspective in the light of postmodern insights. Curriculum Studies, 5(2), 177-193. https://doi.org/10.1080/14681369700200007

Smyth, E. (2015). Wellbeing and school experiences among 9- and 13-year-olds: Insights from the growing up in ireland study. https://www.esri.ie/publications/wellbeing-and-school-experiences-among-9-and-13-year-olds-insights-fromthe-growing-up-in-ireland-study/

Stanko, E. A., \& Hobdell, K. (1993). Assault on men: Masculinity and male victimization. British Journal of Criminology, 33 (3), 400-415. https://www.jstor.org/stable/23637803

Streitmatter, J. (2012). Perceptions of a single-sex class experience: Females and males see it differently. In A. Datnow \& L. Hubbard (Eds.), Gender in policy and practice: Perspectives on single sex and coeducational schooling (pp. 212-216). Taylor and Francis.

Stringer, D. M. (2013). Negative affect. In M. Gellman \& J. R. Turner (Eds.), Encyclopedia of behavioral medicine. Springer. doi.org/10.1007/978-1-4419-1005-9_606

Stromquist, N. P. (2007). The gender socialization process in schools: A cross-national comparison. Paper commissioned for the EFA Global Monitoring Report 2008 website. http://unesdoc.unesco.org/images/0015/001555/155587e.pdf

Struch, N., \& Schwartz, S. H. (1989). Intergroup aggression: Its predictors and distinctness from in-group bias. Journal of Personality and Social Psychology, 56(3), 364-373. https://doi.org/10.1037/0022-3514.56.3.364

Tichenor, M. S., Tichenor, J. M., Piechura-Coture, K., \& Heins, B. (2012). Hearing the voices of parents in single-gender classes. Advances in Gender and Education, 3, 7-13. http://www.stetson.edu/artsci/education/hollis-institute/media/ ParentArt11.pdf

United Nations Educational, Scientific, and Cultural Organization (UNESCO). (2007). Single-SEX SCHOOLS FOR GIRLS AND GENDER EQUALITY IN EDUCATION. UNESCO.

Van Dijk, J. (2009). Free the victim: A critique of the western conception of victimhood. International Review of Victimology, 16(1), 1-33. https://doi.org/10.1177/026975800901600101 